\title{
Pengaruh Psikoedukasi tentang Pengetahuan ADHD terhadap Kemampuan Guru dalam Melakukan Deteksi Dini Masalah ADHD pada Siswa dan Keterampilan Intervensi Kelas
}

\author{
Ana Karunia \\ Ika Yuniar Cahyanti \\ Fakultas Psikologi Universitas Airlangga Surabaya
}

\begin{abstract}
This study aimed to see the effect of psychoeducation on teacher's ability to do early detection of ADHD students and classroom intervention skills. Design of this study was quasi experiment with experiment and control group subject. Data collection techniques in this study were Evaluation $A D H D$ Early Detection and Evaluation of Classroom Intervention Skills. Data analysis technique in this study was independent sample t-test using SPSS 16 for windows. The results of this study showed that psychoeducation about ADHD knowledge affected teacher ability to ADHD early detection skills problems on students $(p<0.05)$. The study also proved that psychoeducation about ADHD affected classroom intervention skills ( $p<0.05)$. Research findings showed that ADHD psychoeducation significantly influenced teacher ability to obtain higher level of ADHD early detection skills on students and classroom intervention skills.
\end{abstract}

Keywords: $A D H D$ knowledge, classroom intervention skills, ADHD early detection skills, psychoeducation.

\begin{abstract}
Abstrak.
Penelitian ini bertujuan untuk mengetahui pengaruh psikoedukasi terhadap kemampuan guru dalam melakukan deteksi dini masalah ADHD pada siswa dan keterampilan intervensi kelas. Desain penelitian ini adalah eksperimen kuasi dengan dua kelompok partisipan, kelompok eksperimen dan kelompok kontrol. Teknik pengumpulan data dalam penelitian ini menggunakan Evaluasi Kemampuan Deteksi Dini ADHD dan Evaluasi Keterampilan Intervensi Kelas. Teknik analisis data menggunakan independent sample t-test. Hasil penelitian ini adalah psikoedukasi tentang pengetahuan $A D H D$ berpengaruh secara signifikan terhadap kemampuan guru melakukan deteksi dini masalah $A D H D$ pada siswa (p<0.05). Penelitian ini juga membuktikan bahwa psikoedukasi tentang pengetahuan ADHD berpengaruh secara signifikan terhadap ketrampilan guru melakukan intervensi kelas $(p<0.05)$. Kesimpulan dari penelitian ini adalah psikoedukasi mengenai $A D H D$ terbukti berpengaruh secara signifikan terhadap kemampuan guru melakukan deteksi dini masalah ADHD pada siswa dan keterampilan intervensi kelas.
\end{abstract}

Kata kunci: deteksi dini $A D H D$, keterampilan, intervensi kelas, pengetahuan tentang $A D H D$, psikoedukasi.

\footnotetext{
Korespondensi: Departemen Psikologi Klinis dan Kesehatan Mental Fakultas Psikologi Universitas Airlangga, J. Dharmawangsa Dalam Selatan Surabaya 60286, e-mail: ${ }^{1}$ ana.karunia-12@psikologi.unair.ac.id, ika.yuniar@psikologi.unair.ac.id
} 


\section{PENDAHULUAN}

Attention Deficit Hyperactivity Disorder (ADHD) adalah pola menetap dari kurangnya perhatian, hiperaktivitas dan impulsivitas yang tampak lebih sering dan lebih parah daripada yang biasanya diamati pada individu lain dengan level perkembangan yang sama (American Psychiatric Association, 200o). ADHD adalah salah satu gangguan kejiwaan yang paling sering didiagnosiskan oleh psikiater padaanak-anak.

Presentase anak usia sekolah di Indonesia yang didiagnosis ADHD belum diketahui secara pasti. Data yang diperoleh pada tahun 2002 hingga 2004 menyatakan prevalensi ADHD di Indonesia paling sedikit terjadi pada 10\% populasi anak dan remaja usia 3-18 tahun (Saputro, 2004), dan data tahun 2009 menunjukkan peningkatan menjadi $15,8 \%$ dari populasi anak berusia 318 tahun (Saputro, 2009). Di Surabaya, data yang diperoleh dari Unit Psikiatri Anak (Day Care) RSUD Dr. Soetomo Surabaya menunjukkan adanya peningkatan jumlah pasien anak ADHD dengan berbagai karakteristik dari tahun 2000-2001, yaitu sebesar 43,33\% (dari 6o anak menjadi 86 anak). Dari 86 anak ADHD terdapat 60 anak laki-laki (70\%) dan 26 anak perempuan (30\%) yang terdiri dari usia 3 tahun sampai diatas 12 tahun (Mulyono, 2003).

Jumlah siswa dengan ADHD di Sekolah Dasar X Surabaya yang menjadi konteks penelitian ini juga menunjukkan peningkatan yang signifikan dari tahun ajaran 2013-2014 hingga tahun ajaran 2015-2016. Pada tahun ajaran 2013-2014 jumlah siswa dengan ADHD yang tercatat berjumlah 4 anak yang tersebar di kelas 1 hingga kelas 6. Pada tahun ajaran 20142015 jumlah siswa dengan ADHD bertambah menjadi 5 anak, dan pada tahun ajaran 2015-2016 jumlah siswa dengan ADHD bertambah menjadi 8 anak.

Siswa dengan ADHD menunjukkan tiga gejala utama yaitu sulit mempertahankan perhatian, hiperaktivitas dan perilaku impulsif. Saputro (2001) menyatakan bahwa banyak gejala ADHD yang baru teridentif ikasi saat anak memasuki usia sekolah dimana anak dituntut untuk mematuhi aturan-aturan sekolah, mengerjakan tugas, duduk diam di kelas dan memiliki pemusatan perhatian yang baik. Oleh sebab itu, guru dituntut untuk memiliki pengetahuan yang cukup tentang ADHD.

Guru memiliki keunggulan dalam melakukan deteksi dini ADHD karena sekolah merupakan tempat dimana ada kontak setiap hari dengan anak yang sama, sehingga gejala ADHD sangat terlihat dan dapat diamati (Syed \& Husein, 2009). Selain itu kriteria diagnosis ADHD menurut DSM IV-TR membutuhkan gejala hiperaktif-impulsif atau kurangnya perhatian tampak pada 2 atau lebih setting, seperti di rumah dan di sekolah. Persyaratan ini menekankan keunggulan informasi dari guru dalam membuat diagnosis ADHD. Psikolog atau tenaga medis akan membutuhkan informasi dari guru, bukan hanya untuk menetapkan diagnosis, tetapi juga untuk merencanakan intervensi yang paling tepat untuk anak (DuPaul \& Stoner, 2003; Wolraich dkk, 2003; Saputro, 2009).

Pentingnya posisi guru dalam melakukan deteksi dini masalah ADHD pada siswa tidak diimbangi dengan pengetahuan guru berkaitan dengan ciri-ciri ADHD, penyebab ADHD, dan akibat dari gangguan tersebut. Hanya sedikit guru yang pernah menerima pelatihan tentang ADHD, padahal pengetahuan yang tinggi mengenai gangguan ini dapat membantu mengurangi kesalahpahaman dan prasangka yang merugikan tentang ADHD (Alkahtani, 2013).

Berdasarkan wawancara dengan lima orang guru di SD X Surabaya, pengetahuan guru-guru di sekolah tersebut mengenai gangguan ADHD sangat kurang. Guru-guru memiliki pengetahuan yang sedikit mengenai ciri-ciri perilaku ADHD, cara mendeteksi gangguan ADHD pada siswa, penyebab gangguan $\mathrm{ADHD}$, akibat dari gangguan tersebut, terapi untuk ADHD, dan penangananyang tepat untuk siswa dengan ADHD. Para guru menganggap siswa dengan ADHD adalah anak nakal, pembangkang, malas, mudah bosan, 
semau sendiri, pembuat onar di kelas, terlalu banyak bergerak, melanggar peraturanperaturan sekolah, dan bodoh. Siswa dengan ADHD juga dianggap cenderung agresif dan tidak ragu menyakiti temannya. Para guru menganggap penyebab ADHD adalah kesalahan pengasuhan orangtua, pengaruh makanan yang dikonsumsi dan faktor keturunan. Sedangkan akibat dari ADHD yang diketahui adalah mengganggu proses belajar di kelas, nilai yang buruk dan tidak naik kelas.

Para guru mengungkapkan belum melakukan deteksi masalah ADHD atau deteksi gangguan-gangguan lain pada siswa mereka walaupun ada kecenderungan peningkatan jumlah siswa dengan kebutuhan khusus. Para guru juga seringkali tidak tahu apa yang harus dilakukan untuk menangani siswa-siswa tersebut sehingga disamaratakan dengan siswa normal pada umumnya. Ketika mereka mengganggu situasi kelas, atau melanggar peraturan sekolah, guru memberikan teguran dan hukuman supaya mereka tidak mengulangi perbuatannya lagi, tetapi siswa-siswa tersebut selalu mengulangi kembali perbuatan mereka dan sulit sekali merubah perilaku mereka.

Deteksi dini gangguan ADHD yang dilakukan sejak dini, terutama saat usia sekolah sangat penting dilakukan untuk meminimalisasi gejala dan akibat yang ditimbulkannya di kemudian hari. Apabila ADHD tidak dideteksi sejak dini dan mendapatkan terapi yang memadai, akibat yang ditimbulkan sangat luas yaitu menghambat tahapan perkembangan psikososial anak sehingga menimbulkan kegagalan dalam bidang akademik, sosial dan harga diri yang rendah (Saputro, 2001; U.S. Department of Education, 2008). Deteksi dini ADHD harus melibatkan beberapa lapisan masyarakat seperti tenaga medis, guru dan orangtua. Bila gejala ADHD terdeteksi sejak dini maka akan lebih mudah mengarahkan pola pendidikan dan pengasuhan anak dengan ADHD (Judarwanto, 2009).

Rendahnya pengetahuan guru tentang ADHD, rendahnya kemampuan guru dalam melakukan deteksi dini ADHD, belum tersedianya instrumen untuk deteksi dini masalah ADHD di SD X, serta rendahnya keterampilan intervensi kelas mendorong peneliti untuk merancang sebuah intervensi dengan pendekatan psikoedukasi tentang pengetahuan ADHD untuk meningkatkan kemampuan guru dalam melakukan deteksi dini masalah ADHD pada siswa dan keterampilan melakukan intervensi kelas.

Intervensi psikoedukasi tentang pengetahuan ADHD dipilih oleh peneliti karena berdasarkan penelitian-penelitian sebelumnya, psikoedukasi tentang pengetahuan ADHD secara signifikan berpengaruh pada pengetahuan dan kesadaran guru pada gejalagejala ADHD, meningkatkan keterampilan guru mengidentifikasi gejala ADHD dengan menggunakan instrumen terstandar, dan meningkatkan keterampilan intervensi kelas (Adriyati, 2015; Syed \& Husein, 2009; Aguiar, 2013; Alkahtani, 2013, Piwowar, 2013).

Pengetahuan tentang ADHD yang diberikan kepada guru-guru di sekolah dasar mencakup definisi ADHD, etiologi ADHD, gejala yang tampak, jenis-jenis ADHD, akibat dari ADHD, diagnosis pembanding dan komorbid, terapi untuk ADHD dan manajemen ADHD di sekolah mengenalkan instrumen deteksi ADHD, dan alur rujukan. Penting untuk guru untuk tidak hanya memiliki pengetahuan tentang ADHD, tetapi juga jika mereka benarbenar terampil melakukan deteksi dini gangguan ADHD dan tahu bagaimana mengimplementasikan intervensi kelas (Barbaresi \& Olsen, 1998; Syed \& Husein, 2009; Aguiar, 2013).

Berangkat dari latar belakang tersebut, tujuan dari penelitian ini adalah untuk mengetahui ada atau tidaknya pengaruh psikoedukasi tentang pengetahuan ADHD terhadap kemampuan guru dalam melakukan deteksi dini masalah ADHD pada siswa dan keterampilan intervensi kelas di sekolah dasar X.

\section{Hipotesis 1}

Ho: Psikoedukasi tentang pengetahuan 
Pengaruh Psikoedukasi tentang Pengetahuan ADHD terhadap Kemampuan Guru dalam Melakukan Deteksi Dini ...

ADHD tidak berpengaruh terhadap kemampuan guru dalam melakukan deteksi dini masalah ADHD pada siswa.

Ha: Psikoedukasi tentang pengetahuan ADHD berpengaruh terhadap kemampuan guru dalam melakukan deteksi dini masalah ADHD pada siswa.

\section{Hipotesis 2}

Ho: Psikoedukasi tentang pengetahuan ADHD tidak berpengaruh untuk meningkatkan keterampilan intervensi kelas guru.

Ha: Psikoedukasi tentang pengetahuan ADHD berpengaruh untuk meningkatkan keterampilan intervensi kelas guru.

\section{METODE}

\section{Desain penelitian}

Metode penelitian yang digunakan dalam penelitian ini adalah penelitian kuantitatif dengan metode eksperimen. Desain penelitian pada penelitian ini menggunakan desain quasiexperimental research (penelitian eksperimen semu) dengan non-randomized pretest-postest control group design.

Penelitian ini menggunakan desain dua kelompok nonrandomized pretest-post test control group. Pada desain ini juga dilakukan pretest dan post test untuk melakukan kontrol konstansi terhadap proactive history.

\section{Variabel}

Variabel bebas pada penelitian ini adalah psikoedukasi tentang pengetahuan ADHD. Variabel terikat pada penelitian ini adalah kemampuan guru dalam melakukan deteksi dini masalah ADHD pada siswa di Sekolah Dasar $\mathrm{X}$ dan keterampilan intervensi kelas pada guru di Sekolah DasarX. Sedangkan partisipan dalam penelitian ini merupakan guru wali kelas 1 hingga kelas 6 dan guru bidang studi yang mengajar di SD X, belum pernah mengikuti pelatihan tentang ADHD, serta bersedia mengikuti keseluruhan rangkaian kegiatan pelatihan dari awal hingga akhir yang dinyatakan dalam informed consent. Dari 23 orang guru di SD X, peneliti memperoleh 9 orang guru yang dapat menjadi partisipan penelitian di kelompok eksperimen dan 9 orang guru yang menjadi kelompok kontrol

\section{Teknik pengumpulan data}

Alat pengumpulan data yang digunakan dalam penelitian ini adalah Skala Penilaian Perilaku Anak Hiperaktif Indonesia (SPPAHI). SPPAHI adalah instrumen penilaian perilaku yang dirancang khusus untuk mendeteksi gangguan ADHD pada anak usia 6-13 tahun dan dikembangkan sesuai dengan ciri perilaku anak ADHD di Indonesia. Kemampuan guru dalam melakukan deteksi dini masalah ADHD menggunakan SPPAHI diukur menggunakan metode pencatatan checklist. Penilaian dilakukan sebelum dan sesudah diberikannya pelatihan sebagai pretest dan post test kemampuan guru dalam melakukan deteksi dini masalah ADHD pada siswa. Pretest dan post test kemampuan guru dalam melakukan deteksi dini masalah ADHD pada siswa diberikan kepada setiap peserta dalam bentuk kasus nyata satu siswa yang sudah memiliki diagnosis ADHD. Setiap guru diminta untuk mempraktikkan cara menggunakan SPPAHI yang meliputi pengadministrasian SPPAHI, pemberian skor, interpretasi total skor, dan pemberian rujukan atau rekomendasi.

Keterampilan intervensi kelas untuk siswa ADHD yang dimiliki guru diukur menggunakan metode checklist. Pretest dan post test keterampilan intervensi kelas diberikan kepada setiap peserta dalam bentuk blindcase berdasarkan gejala-gejala ADHD yang muncul di sekolah dan paling banyak ditemui oleh guru. Setiap partisipan penelitian kemudian diminta untuk menuliskan rancangan intervensi berdasarkan blindcase tersebut dan diminta untuk melakukan roleplay.

\section{Teknik analisis data}

Teknik analisis data kuantitatif yang akan digunakan yaitu uji asumsi data, yakni menggunakan uji normalitas. Analisis selanjutnya adalah pengujian hipotesis. Uji parametrik akan digunakan jika data normal, namun jika tidak akan dilakukan uji non- 
parametrik. Uji hipotesis dilakukan menggunakan Independent Sample T-Test.

\section{Hasil Penelitian}

Hasil analisis deskriptif kemampuan deteksi dini masalah ADHD pada siswa di kelompok eksperimen dan kelompok kontrol. Seluruh partisipan dalam kelompok eksperimen menunjukkan nilai gain score positif yang berkisar 2 hingga 10. Hal ini menunjukkan bahwa semua peserta psikoedukasi pada kelompok eksperimen menunjukkan peningkatan kemampuan deteksi dini masalah ADHD pada siswa.

Pada kelompok kontrol, tidak semua peserta kelompok kontrol mengalami peningkatan kemampuan deteksi dini masalah ADHD. Peningkatan kemampuan deteksi dini masalah ADHD hanya dialami oleh 3 orang dengan peningkatan skor 1 poin. Peningkatan kemampuan deteksi dini masalah ADHD pada kelompok kontrol lebih rendah bila dibandingkan peningkatan kemampuan deteksi dini masalah ADHD pada kelompok eksperimen yang memperoleh psikoedukasi.

Analisis deskriptif keterampilan intervensi kelas untuk siswa ADHD dilakukan sebelum dan sesudah psikoedukasi pada kelompok eksperimen dan kelompok kontrol. Seluruh partisipan dalam kelompok eksperimen menunjukkan nilai gain score positif yang berkisar 11 hingga 21. Hal ini menunjukkan bahwa semua peserta psikoedukasi pada kelompok eksperimen menunjukkan peningkatan keterampilan intervensi kelas. Pada kelompok kontrol, 6 peserta kelompok kontrol menunjukkan peningkatan nilai gain score yang berkisar 1 sampai 3. Sedangkan 3 peserta kelompok kontrol tidak menunjukkan peningkatan nilai gain score. Peningkatan keterampilan intervensi kelas pada kelompok kontrol relatif rendah bila dibandingkan peningkatan pengetahuan kelompok eksperimen yang memperoleh psikoedukasi.

Ada 2 hipotesis yang hendak diuji dalam penelitian ini:

\section{Hipotesis 1}

Ho: Psikoedukasi tentang pengetahuan ADHD tidak berpengaruh terhadap kemampuan guru melakukan deteksi dini masalah ADHD pada siswa.

Ha: Psikoedukasi tentang pengetahuan ADHD berpengaruh terhadap kemampuan guru melakukan deteksi dini masalah ADHD pada siswa.

Tabel 1.

Rata-Rata Skor Kemampuan Deteksi Dini ADHD

\begin{tabular}{lcc}
\hline Kelompok & N & Rata-rata \\
\hline Eksperimen & 9 & 6.22 \\
Kontrol & 9 & 0.33 \\
\hline
\end{tabular}

Tabel 1 menunjukan rata-rata data kelompok eksperimen sebesar 6.22 dan rata-rata dari kelompok kontrol sebesar 0.33. Kedua kelompok mengalami peningkatan kemampuan melakukan deteksi dini masalah ADHD pada siswa, tetapi nilai kelompok eksperimen yang telah diberi psikoedukasi memiliki nilai yang jauh lebih tinggi daripada kelompok kontrol.

Tabel 2. Hasil Independent Sample T-Test Hipotesis 1

\begin{tabular}{llcccc}
\hline Variabel & & $\mathbf{F}$ & $\mathbf{p}$ & $\mathbf{T}$ & $\mathbf{p}$ \\
\hline & Varian & & & & \\
$\begin{array}{l}\text { Peningkatan } \\
\text { kemampuan } \\
\text { deteksi dini }\end{array}$ & diasumsikan & 12.755 & 0.003 & 6.172 & 0.000 \\
ADHD & $\begin{array}{l}\text { Varian } \\
\text { diasumsikan } \\
\text { tidak sama }\end{array}$ & & & & \\
& & & & & \\
& & & & & \\
\hline
\end{tabular}


Di tabel 2, uji hipotesis menggunakan independent sample t-test menunjukkan hasil Ho ditolak ( $\mathrm{p}<0.05)$. Artinya terdapat perbedaan kemampuan guru dalam melakukan deteksi masalah ADHD pada siswa yang telah diberi perlakuan psikoedukasi tentang pengetahuan ADHD dibandingkan kelompok kontrol yang tidak memperoleh perlakuan psikoedukasi tentang pengetahuan ADHD. Hal ini membuktikan bahwa perlakuan yang diberikan pada kelompok eksperimen berhasil atau berpengaruh terhadap kemampuan guru dalam melakukan deteksi masalah ADHD pada siswa.

\section{Hipotesis 2}

Ho: Psikoedukasi tentang pengetahuan ADHD tidak berpengaruh terhadap keterampilan intervensi kelas.

Ha: Psikoedukasi tentang pengetahuan ADHD berpengaruh terhadap keterampilan intervensi kelas.

Tabel 3.

Rata-Rata Skor Keterampilan Intervensi Kelas

\begin{tabular}{lcc}
\hline Kelompok & N & Rata-rata \\
\hline Eksperimen & 9 & 14.67 \\
Kontrol & 9 & 1.11 \\
\hline
\end{tabular}

Tabel 3 menunjukan rata-rata dari kelompok eksperimen sebesar 14.67 dan ratarata dari kelompok kontrol sebesar 1.11. Kedua kelompok mengalami peningkatan keterampilan intervensi kelas, tetapi nilai kelompok eksperimen yang telah diberi psikoedukasi memiliki nilai yang lebih tinggi daripada kelompok kontrol.
Tabel 4 menunjukan nilai homogenitas pada kolom varian diasumsikan sama adalah (p>0.05). Hal ini menunjukkan bahwa varian kedua kelompok tidak homogen sehingga nilai uji-t yang digunakan adalah varian diasumsikan tidak sama $(\mathrm{p}<0.05)$. Uji hipotesis menggunakan independent sample t-test menunjukkan hasil Ho ditolak ( $<<0.05$ ). Artinya terdapat perbedaan keterampilan intervensi kelas pada guru yang telah diberi perlakuan psikoedukasi tentang pengetahuan ADHD dibandingkan kelompok kontrol yang tidak memperoleh perlakuan psikoedukasi tentang pengetahuan ADHD. Hal ini membuktikan bahwa perlakuan yang diberikan pada kelompok eksperimen berhasil atau berpengaruh terhadap keterampilan intervensi kelas guru sekolah dasar.

\section{DISKUSI}

Berdasarkan hasil pengujian hipotesis secara statistik, terdapat perbedaan yang signifikan pada kemampuan guru dalam melakukan deteksi dini masalah ADHD pada siswa di kelompok eksperimen yang memperoleh psikoedukasi dibandingkan dengan kelompok kontrol yang tidak memperoleh psikoedukasi. Hal ini menunjukkan bahwa psikoedukasi tentang pengetahuan ADHD memiliki pengaruh terhadap kemampuan guru melakukan deteksi dini masalah ADHD pada siswa. Hasil pengujian hipotesis kedua secara statistik juga menunjukkan terdapat perbedaan yang signif ikan pada keterampilan intervensi kelas di kelompok eksperimen yang memperoleh

Tabel 4. Hasil Independent Sample T-Test Hipotesis 2

\begin{tabular}{llcccc}
\hline Variabel & & $\mathbf{F}$ & $\mathbf{p}$ & $\mathbf{T}$ & $\mathbf{p}$ \\
\hline $\begin{array}{l}\text { Peningkatan } \\
\text { keterampilan }\end{array}$ & $\begin{array}{l}\text { Varian } \\
\text { diasumsikan }\end{array}$ & 8.530 & 0.010 & 11.231 & 0.000 \\
sama & & & & & \\
kelas & $\begin{array}{l}\text { Varian } \\
\text { diasumsikan } \\
\text { tidak sama }\end{array}$ & & & 11.231 & 0.000 \\
& & & & & \\
\hline
\end{tabular}


psikoedukasi dibandingkan dengan kelompok kontrol yang tidak memperoleh psikoedukasi. Hal ini menunjukkan bahwa psikoedukasi tentang pengetahuan ADHD memiliki pengaruh terhadap keterampilan intervensi kelas.

Pengaruh psikoedukasi tentang pengetahuan ADHD terhadap kemampuan guru melakukan deteksi dini masalah ADHD pada siswa dapat dilihat dari pemaparan hasil deskriptif penelitian, dimana sembilan partisipan dalam kelompok eksperimen mengalami peningkatan skor kemampuan melakukan deteksi dini masalah ADHD pada siswa. Gain score kemampuan guru melakukan deteksi dini masalah ADHD pada siswa di kelompok eksperimen berkisar dari 2 hingga 10. Rata-rata skor kemampuan deteksi dini masalah ADHD pada kelompok eksperimen ketika pretest adalah 12.89 dan naik menjadi 19.11 ketika post test.

Pada kelompok kontrol yang tidak diberi perlakuan tidak terdapat perbedaan signifikan pada pretest dan post test kemampuan guru melakukan deteksi dini masalah ADHD pada siswa. Dari 9 orang partisipan kelompok kontrol, hanya 3 orang yang mengalami peningkatan skor dalam kemampuan melakukan deteksi dini masalah ADHD pada siswa, sedangkan 6 orang lainnya tidak mengalami peningkatan skor.

Pengaruh psikoedukasi tentang ADHD terhadap kemampuan guru melakukan deteksi dini masalah ADHD juga dapat dilihat dari pengisian pretest dan post test kemampuan guru melakukan deteksi dini ADHD terhadap salah seorang siswanya. Ketika pretest, para partisipan penelitian di kelompok eksperimen masih banyak mengalami kesulitan dalam pengadministrasian SPPAHI. Para partisipan penelitian di kelompok eksperimen belum mampu memberikan informasi dengan benar mengenai identitas siswa serta belum mampu menuliskan masalah perilaku dan prestasi akademis maupun non-akademis dengan jelas. Para partisipan penelitian juga belum mampu memberikan skor dengan tepat pada kemunculan beberapa perilaku ADHD, seperti belum mampu dalam melihat kemunculan perilaku ketidakmampuan memusatkan perhatian pada siswa. Para partisipan penelitian di kelompok eksperimen juga masih salah dalam menghitung jumlah skor, tidak memahami arti jumlah skor dalam SPPAHI dan tidak mengetahui alur rujukan bila siswa berisiko tinggi mengalami ADHD.

Setelah pemberian psikoedukasi tentang pengetahuan ADHD, kemampuan partisipan penelitian kelompok eksperimen dalam mendeteksi masalah ADHD pada siswa meningkat. Kesalahan pada pengadministrasian identitas siswa masih terjadi, tetapi seluruh partisipan dalam kelompok eksperimen mampu mengamati dan memberikan penilaian terhadap ciri-ciri perilaku ADHD pada siswa, yaitu kesulitan mempertahankan perhatian, hiperaktivitas dan impulsivitas. Para partisipan dalam kelompok eksperimen juga mampu menghitung skor dalam SPPAHI dengan tepat. memahami arti dari skor tersebut dan mengetahui alur rujukan bila siswa berisiko tinggi mengalami ADHD.

Psikoedukasi tentang pengetahuan ADHD pada penelitian ini juga berpengaruh terhadap keterampilan intervensi kelas. Gain score keterampilan intervensi kelas pada kelompok eksperimen berkisar 11 hingga 21. Rata-rata skor keterampilan intervensi kelas siswa ADHD pada kelompok eksperimen ketika pretest adalah 3 dan naik menjadi 17.67 ketika post test. Pada kelompok eksperimen, pengaruh psikoedukasi tentang pengetahuan ADHD terhadap keterampilan intervensi kelas dapat dilihat dari keterampilan peserta kelompok eksperimen melakukan teknik-teknik intervensi kelas. Setelah pemberian psikoedukasi, para partisipan penelitian di kelompok eksperimen mampu mengidentifikasi masalah perilaku pada siswa, mengidentifikasi kebutuhan siswa, serta memilih dan merancang teknik-teknik intervensi kelas yang sesuai untuk masalah siswa yang terdapat di blindcase.

Pada kelompok kontrol yang tidak memperoleh perlakuan, peningkatan skor post 
test keterampilan intervensi kelas juga terjadi sebesar 1.111. Peningkatan ini jauh lebih rendah dibandingkan kelompok eksperimen yang memperoleh psikoedukasi. Peningkatan keterampilan intervensi kelas pada kelompok kontrol dialami oleh 6 orang kelompok kontrol yang memiliki pengalaman berkaitan dengan siswa ADHD. Para guru tersebut rata-rata pernah memiliki 1 sampai 5 siswa dengan ADHD dan pernah mencari informasi berkaitan dengan gangguan ADHD melalui internet, buku, maupun artikel. Hal ini tidak dimiliki oleh 3 orang kelompok kontrol lainnya yang tidak mengalami peningkatan keterampilan intervensi kelas. Mereka tidak memiliki pengalaman mengajar siswa dengan ADHD serta tidak pernah mencari informasi berkaitan dengan gangguan ADHD.

Berdasarkan hasil wawancara dengan partisipan kelompok kontrol, peningkatan skor post test keterampilan intervensi kelas pada kelompok kontrol disebabkan mereka telah mencari informasi mengenai kegiatan yang dilakukan kelompok eksperimen. Kelompok kontrol juga membaca buku materi kelompok eksperimen sehingga pengetahuan mengenai teknik-teknik intervensi kelas juga mengalami peningkatan. Kelompok eksperimen dan kelompok kontrol yang berada di satu lingkungan kerja membuat peneliti sulit untuk mengontrol tersebarnya informasi di dalam kelompok tersebut.

Hasil temuan tersebut sesuai dengan penelitian dari Jones dan Tuscano (2008) yang mengungkapkan bahwa guru yang pernah memiliki siswa dengan ADHD lebih terlatih untuk menangani siswa dengan ADHD daripada guru yang sama sekali belum pernah memiliki siswa dengan ADHD. Penelitian Barbaresi dan Olsen (1998) dan Jerome dkk. (1994 dalam Jones \& Tuscano, 20o8) mengungkapkan peningkatan skor post test keterampilan intervensi kelas pada kelompok kontrol sebesar 1 hingga 3 poin dikarenakan pada dasarnya kelompok kontrol telah memiliki keterampilan intervensi kelas berkaitan dengan profesi mereka sebagai guru. Hal ini dapat dilihat dari skor pretest keterampilan intervensi kelas kelompok kontrol. Jones dan Tuscano (2008) juga menyebutkan faktor peningkatan skor keterampilan intervensi kelas di kelompok kontrol merupakan faktor yang tidak dapat dikontrol sepenuhnya oleh peneliti karena peserta kelompok kontrol dapat mencari informasi berkaitan dengan teknik-teknik intervensi kelas melalui berbagai media.

Hasil yang diperoleh pada penelitian ini mendukung beberapa penelitian serupa yang telah dilakukan sebelumnya, seperti penelitian dari Syed dan Husein (2010) yang membuktikan bahwa pelatihan berhubungan dengan peningkatan kesadaran pada banyaknya tanda dan gejala ADHD dan dapat meningkatkan pemahaman dan pengakuan pada anak-anak dengan ADHD. Penelitian ini membuktikan bahwa pelatihan yang berisi tentang informasi umum ADHD, pengenalan alat ukur untuk mendeteksi gejala ADHD dan keterampilan manajemen kelas efektif untuk meningkatkan pemahaman guru pada anak-anak dengan ADHD, serta meningkatkan kesadaran guru pada gejala-gejala ADHD. Pelatihan ini juga menjelaskan pentingnya posisi guru untuk mengidentifikasi anak yang berisiko. Guru memiliki posisi yang lebih baik daripada tenaga kesehatan lainnya karena mereka bertemu dengan anak yang sama setiap hari dan tempat dimana gejala ADHD dapat terlihat. Hal ini membuat guru harus memiliki pengetahuan yang cukup untuk mengidentifikasi anak dengan ADHD.

Hasil dari penelitian ini juga mendukung penelitian dari Aguiar, dkk. (2013) yang menyatakan bahwa program intervensi psikoedukasi singkat secara signifikan meningkatkan pengetahuan dan pemahaman tentang ADHD. Hal ini membuktikan bahwa psikoedukasi yang berisi gambaran klinis gangguan, prevalensi, etiologi dan strategi manajemen ADHD di sekolah dapat meningkatkan pengetahuan dan pemahaman guru tentang ADHD dan gejala-gejalanya, sekaligus meningkatkan keterampilan intervensi kelas. Penelitian ini juga 
menekankan peran guru yang sangat penting untuk melakukan deteksi awal pada gangguan ADHD, supaya anak yang berisiko tinggi mengalami ADHD mendapat penanganan yang sesuai.

Penelitian ini juga mendukung penelitian dari Ardiyati (2015) yang bertujuan untuk menguji pengaruh pelatihan ADHD dalam meningkatkan pengetahuan tentang ADHD pada kelompok orangtua dan guru dan pengaruh peningkatan pengetahuan ADHD dalam meningkatkan ketepatan melakukan deteksi dini. Hasil penelitian menunjukkan pelatihan ini terbukti dapat meningkatkan pemahaman tentang ADHD dengan sumbangan efektif sebesar $79 \%$ juga meningkatkan ketepatan orangtua dan guru dalam melakukan deteksi dini.

Hasil dari penelitian yang menyatakan terdapat peningkatan keterampilan intervensi kelas setelah dilaksanakannya psikoedukasi mendukung penelitian dari Garcia (2004). Hasil penelitian menunjukkan pengaruh pelatihan terhadap peningkatan pengetahuan tentang ADHD dan dukungan dari guru untuk melakukan beberapa teknik intervensi kelas seperti mendudukkan siswa di depan kelas, mengukur kebutuhan dan kekuatan siswa, serta menggunakan teknologi untuk siswa dengan ADHD. Penelitian dari Jones dan Chronis (2006) juga menunjukkan adanya peningkatan pengetahuan ADHD pada kelompok eksperimen dan terdapat peningkatan penggunaan teknik modifikasi perilaku setelah diberikan pelatihan.

Seperti penelitian dari Syed dan Husein (2010), Aguiar, dkk. (2012), Ardiyati (2015), Garcia (2004) dan Jones dan Chronis (2006), penelitian ini juga membuktikan bahwa psikoedukasi ADHD mampu meningkatkan pengetahuan guru tentang ADHD, meningkatkan kemampuan guru dalam mendeteksi masalah ADHD pada siswa, serta meningkatkan keterampilan guru melakukan intervensi kelas.

Berdasarkan wawancara singkat dengan beberapa peserta psikoedukasi setelah beberapa hari diberikan psikoedukasi, para peserta menjadi lebih memahami gangguan ADHD pada anak serta lebih berempati pada anak-anak yang memunculkan gejala ADHD. Selain itu, partisipan mengembangkan pemahaman bahwa perilaku mereka bukan karena mereka nakal atau dengan sengaja membangkang tetapi akibat dari gangguannya, sehingga mereka kesulitan mempertahankan perhatian atau terlalu banyak bergerak. Para partisipan penelitian juga lebih menyadari bahwa peran mereka sebagai guru sangat penting untuk mendeteksi masalah ADHD pada siswa-siswa mereka supaya siswa yang terdeteksi berisiko tinggi mengalami ADHD dapat segera dirujuk ke psikolog atau psikiater agar segera mendapat penanganan yang tepat. Mereka mengatakan akan melakukan deteksi dini masalah ADHD pada siswa di kelas mereka yang dicurigai memiliki masalah perilaku ADHD.

Seluruh peserta psikoedukasi mengatakan telah menggunakan teknik intervensi kelasyang telah dipelajari untuk siswa mereka yang mengalami gangguan ADHD. Teknik intervensi yang digunakan antara lain teknik akomodasi kelas yang dapat digunakan untuk proses belajar seluruh siswa di kelas, memindahkan posisi duduk siswa dengan ADHD di depan kelas dekat guru, penggunaan token ekonomi, response cost, serta pemberian pujian kepada setiap pencapaian siswa walaupun kecil. Teknik-teknik intervensi kelas baru digunakan pada awal tahun pelajaran 2015-2016 setelah dikonsultasikan dengan orangtua siswa.

Hasil wawancara dengan beberapa peserta psikoedukasi setelah beberapa hari diberikan psikoedukasi mengungkapkan bahwa salah satu peserta psikoedukasi, yaitu partisipan T sudah melakukan deteksi dini ADHD kepada salah seorang siswanya di kelas 3 yang menunjukkan perilaku hiperaktif dan impulsif. Siswa tersebut sebenarnya cukup pandai dan mampu menyelesaikan tugas-tugas yang diberikan dan sangat jarang tidak menyelesaikan tugastugasnya. Setelah dilakukan deteksi dini masalah ADHD, mayoritas masalah perilaku yang muncul adalah hiperaktif-impulsif. 
Partisipan T sudah mengkomunikasikan hasil deteksi dini siswa tersebut kepada orangtua dan meminta orangtua untuk memeriksakan siswa tersebut kepada psikolog atau dokter. tetapi orangtua siswa tersebut belum memeriksakannya dengan alasan belum ada waktu untuk memeriksakan anaknya kepada dokter atau psikolog.

\section{SIMPULAN}

Berdasarkan hasil analisis data secara statistik. psikoedukasi tentang pengetahuan ADHD berpengaruh terhadap kemampuan guru melakukan deteksi dini masalah ADHD pada siswa. Setelah mengikuti psikoedukasi tentang ADHD terjadi perbedaan yang signifikan pada kemampuan guru melakukan deteksi dini masalah ADHD antara kelompok eksperimen dengan kelompok kontrol. Berdasarkan hasil analisis data secara statistik. psikoedukasi tentang pengetahuan ADHD juga berpengaruh terhadap keterampilan intervensi kelas antara kelompok eksperimen dengan kelompok kontrol.

Isi psikoedukasi yang menitikberatkan pada pengetahuan umum tentang ADHD meliputi definisi, prevalensi, penyebab ADHD, subtipe ADHD, ciri-ciri perilaku ADHD, pilihan terapi, deteksi dini masalah perilaku ADHD, peran guru dalam melakukan deteksi dini masalah ADHD pada siswa, alur rujukan bila siswa beresiko tinggi mengalami ADHD dan intervensi kelas terbukti memiliki pengaruh terhadap kemampuan guru melakukan deteksi dini masalah ADHD pada siswa dan keterampilan guru melakukan intervensi kelas.

\section{SARAN}

Terdapat saran yang ditujukan pada beberapa pihak, diantaranya para guru yang telah mengikuti psikoedukasi. pihak sekolah, serta untuk peneliti selanjutnya. Bagi para guru yang telah mengikuti psikoedukasi, diharapkan agar melakukan deteksi dini masalah ADHD pada siswa yang dicurigai memiliki ciri-ciri perilaku gangguan ADHD. Bagi pihak sekolah sendiri hendaknya memberikan sosialisasi tentang perilaku anak ADHD kepada orangtua siswa berdasarkan pengamatan guru di sekolah. Pihak sekolah juga perlu menambah informasi mengenai gangguan-gangguan psikologis lain yang dialami pada masa anak-anak.

Anjuran bagi peneliti selanjutnya agar dapat merancang psikoedukasi dengan jangka waktu penelitian lebih panjang dengan memberikan beberapa kali penugasan lapangan yang disertai supervisi, melakukan follow up di lapangan, sehingga mampu melihat efektivitas psikoedukasi yang dilakukan. Hendaknya peneliti menambahkan waktu pelaksanaan intervensi terutama untuk materi keterampilan intervensi kelas supaya peserta lebih memahami teknik-teknik intervensi kelas dan mampu mengaplikasikannya dengan benar. Untuk memperkaya hasil penelitian, peneliti selanjutnya dapat menambahkan variabel lain seperti stres guru sebagai variabel terikat.

\section{PUSTAKA ACUAN}

Adriyati, S.P. (2015). Pelatihan pemahaman ADHD bagi orangtua dan guru untuk meningkatkan kemampuan deteksi dini. Tesis. Tidak diterbitkan. Yogyakarta: Universitas Gadjah Mada.

Aguiar, A.P., Kieling, R.R., Costa, A.C., Chardosim, N., Dorneles, B.V., Almeida, M.R., Mazzuca, A.C., Kieling, C. \& Rohde, L.A. (2013). Increasing teachers' knowledge about ADHD and learning disorders: An investigation on the role of psychoeducational intervention. Journal of Attention Disorders. 18 (8). 691-698.

Alkahtani, K.D.F. (2013). Teacher's knowledge and misconceptions of attention deficit/hyperactivity disorder. Journal of Psychology. 4 (12). 963-969. 
American Psychiatric Association. (200o) Diagnostic and statistical manual of mental disorder (4 $4^{\text {th }}$.ed.). Washington DC:American Psychiatric Association.

Barbaresi, W.J. \& Olsen, R.D. (1998). An ADHD educational intervention for elementary schoolteachers: A pilot study. Developmental and Behavioral Pediatrics. 19 (2).94100.

DuPaul, G.J. \& Stoner, G. (2003). ADHD in the schools assessment and intervention strategies. New York: The Guilford Press.

Garcia, M.J. (2004). Teacher knowledge of attention deficit-hyperactivity disorder (ADHD) and effective classroom interventions. Thesis. Tidak diterbitkan. Los Angeles: California State University.

Jerome, L., Gordon, M., \& Hustler, P. (1994). A comparison of American and Canadian teachers' knowledge and attitudes towards attention deficit hyperactivity disorder. Canadian Journal of Psychiatry. 39. 563567 .

Jones, H.A. (2006). Teacher in-service training for attention deficit/hyperactivity disorder (ADHD): Influence on knowledge about ADHD use of classroom behavior management techniques and teacher stress. Dissertation. Tidak dipublikasikan. Maryland: University of Maryland.

Jones, H.A. \& Chronis-Tuscano, A. (2008). Efficacy of teacher in-service training for attentiondef icit/hyperactivity disorder. Psychology in the schools. 45 (10). 2008.

Judarwanto, W. (2009, 9 Mei). Deteksi dini ADHD (Attention Deficit Hyperactivity Disorders). Terapi Biomedis dan Komunikasi [on-line]. Diakses pada tanggal 8 September 2014 dari http;//puterakembara.org/rm/adhd.shtml.

Mulyono, R. (2003). Menangani anak hiperaktif: Panduan orangtua dan guru dalam membimbing anak yang mengalami gangguan pemusatan perhatian E hiperaktivitas (GPPH). Jakarta:Studia Press.

Piwowar, T.F. \& Ophardt, B. (2013). Training inservice teachers' competencies in classroom management. A quasi-experimental study with teachers of secondary schools. Teaching and Teacher Education. 30.1-12.

Sadock, B.J. \& Sadock, V.A. (2004). Kaplan E sadock buku ajar psikiatri klinis (edisi ke 2). Jakarta: Penerbit Buku Kedokteran EGC.

Saputro, D. (2001). Penatalaksanaan srategis gangguan pemusatan perhatian dan hiperaktivitas (GPPH/ADHD). Aima Indonesian Psychological Journal.17 (1).11-17.

Saputro, D. (2009). ADHD (Attention deficit hyperactivity disorder). Jakarta: Sagung Seto.

Syed, E.U. \& Hussein, S.A. (2010). Increase in teachers' knowledge about ADHD after a week-long training program: A pilot study. Journal of Attention Disorders. 13. 4. 420-423.

U.S. Department of Education. (2008). Identifying and treating attention deficit hyperactivity disorder: A resource for school and home. Washington D.C.: U.S. Department of Education.

U.S. Department of Education. (2008). Teaching children with attention deficit hyperactivity disorder: Instructional stratgies and practices. Washington D.C.:U.S. Department of Education.

U.S. Department Of Health And Human Services. (2012). Attention Deficit Hyperactivity Disorder. National Institute od Mental Health [on-line]. Diakses pada tanggal 16 April 2015 dari http://www.nimh.nih.go 